\title{
PROFESJONALIZACJA KOMUNIKACJI POLITYCZNEJ W DOBIE MEDIATYZACJI: WYZWANIA KONCEPCYJNE I BADAWCZE
}

\author{
THE PROFESSIONALIZATION OF POLITICAL \\ COMMUNICATION IN THE AGE OF MEDIATIZATION: \\ CHALLENGES FOR THEORY AND RESEARCH
}

Barbara Brodzińska-Mirowska* ำ

\begin{abstract}
- ABSTRAKT
$\mathrm{W}$ artykule podejmuję refleksję nad zjawiskiem profesjonalizacji komunikacji politycznej w dobie przeobrażeń wynikających z procesu mediatyzacji. Stanowiskiem wyjściowym w podejmowanej dyskusji jest twierdzenie, że profesjonalizacja kampanii wyborczych nie jest równoznaczna z profesjonalizacją komunikacji politycznej $\mathrm{w}$ ogóle. $\mathrm{W}$ poniższych analizach przyjmuję perspektywę strategicznego podejścia do działań komunikacyjnych podejmowanych przez organizacje partyjne. W pierwszej części dokonuję krytycznej analizy dotychczasowego spojrzenia na proces profesjonalizacji komunikacji politycznej oraz prezentuję wybrane propozycje badawcze, które mają na celu próbę ustrukturyzowania badań profesjonalizacji. W efekcie podjętych analiz, a także na podstawie dotychczasowych doświadczeń badawczych, w drugiej części tekstu proponuję spojrzenie na proces profesjonalizacji z perspektywy sposobu organizacji działań komunikacyjnych przez partie polityczne.
\end{abstract}

The article examines the phenomenon of professionalization of political communication in the age of mediatization. The starting point in the discussion is the statement that professionalization of election campaigns is not synonymous to professionalization of political communication. The discussion is conducted from the strategic approach to communication activities undertaken by party organizations. In the first part, the hitherto recognition of the professionalization process is analyzed. The next step presents selected research methods that attempt to structure professional research. As a result of the previous research experience and undertaken analyzes, a new look at the professionalization process is suggested.

\footnotetext{
* Uniwersytet Mikołaja Kopernika w Toruniu, Wydział Politologii i Studiów Międzynarodowych.
} 
Słowa kluczowe: mediatyzacja; profesjonalizacja; komunikacja polityczna; amerykanizacja
Keywords: mediatization; professionalization; political communication; americanization

\section{WPROWADZENIE}

W dyskursie naukowym przyjęło się określanie komunikacji politycznej mianem profesjonalnej. Profesjonalizacja uznawana jest za zjawisko powszechne i postępujące, a przesłanką do takiego twierdzenia jest przede wszystkim fakt, że w obszar komunikacji politycznej wprowadzane są coraz to nowe narzędzia i techniki komunikacyjne. Wnioski na temat profesjonalizacji formułowane są najczęściej w oparciu o przebieg kampanii wyborczych lub na podstawie analiz tego, jak aktorzy polityczni budują wizerunek medialny. Karen Sanders, Christina Holtz-Bacha i Maria Jose Canel Crespo słusznie zauważają, że pomimo niewielkiego zainteresowania badawczego codziennym (permanentnym) komunikowaniem politycznym, panuje dość powszechny konsensus, że profesjonalizacja komunikacji politycznej zachodzi i, co więcej, obejmuje wiele płaszczyzn komunikacji (2011, s. 524; zob. także Brodzińska-Mirowska, 2013, s. 64-78). Profesjonalizacja komunikacji politycznej, jako wszelkich działań podejmowanych przez partie polityczne, wydaje się w takim kontekście dość nieuprawnioną generalizacją.

Profesjonalizacja kampanii wyborczych, w tym relacji z mediami, jest z jednej strony koniecznością, z drugiej odpowiedzią na kluczową rolę mediów w procesie komunikacji (zob. Brodzińska-Mirowska, 2013; Mazur, 2011; Hess, 2010). Dlatego to właśnie sposób, w jaki organizacje partyjne adaptują się do konieczność kooperacji z mediami, jest często wyznacznikiem profesjonalizacji.

Celem tego artykułu jest zwrócenie uwagi na problematyczne kwestie związane $\mathrm{z}$ badaniem profesjonalizacji komunikacji politycznej i podjęcie krytycznej analizy dotychczasowego ujęcia tego zjawiska. W toku dyskusji chciałabym odpowiedzieć na następujące pytania: 1) w jaki sposób definiowane jest zjawisko profesjonalizacji oraz 2) czy i jak zmieniło się podejście do tego procesu w ostatnim czasie? 3) Jakie czynniki i dlaczego warto uwzględnić w analizach procesu profesjonalizacji? Chcę wskazać także na trudności i ograniczenia, które mogą towarzyszyć próbom strukturyzacji badań stopnia profesjonalizacji. Aby osiągnąć postawiony cel, w pierwszej kolejności dokonany zostanie przegląd dotychczasowych podejść do profesjonalizacji. Odpowiedzią na stawiane w ramach podejmowanej analizy pytania będzie zaproponowanie narzędzia umożliwiającego ocenę profesjonalizacji komunikacji politycznej. 


\section{JEDNOWYMIAROWA PERSPEKTYWA PROFESJONALIZACJI KOMUNIKACJI POLITYCZNEJ? PRZEGLĄD STANOWISK}

Na przestrzeni lat można zauważyć zmianę spojrzenia na proces komunikacji politycznej, w tym także na proces jej profesjonalizacji. Pierwszy okres badań określam mianem ery amerykanizacyjnej. Tym, co w tym okresie charakteryzuje podejście do komunikacji politycznej, a w konsekwencji także do zjawiska profesjonalizacji, jest fakt, że doświadczenia amerykańskie stały się punktem wyjścia dla wielu analiz komunikacji politycznej (skoncentrowanych głównie na komunikacji w okresie kampanii wyborczych) (zob. Blumler, Gurevitch, 1995). Stąd też o profesjonalizacji w analizach naukowych wspomina się głównie w kontekście korzystania z usług specjalistów z zakresu komunikacji' (konsultantów politycznych) (Mancini, 1999; Green, Smith, 2003) oraz wsparcia wyspecjalizowanych agencji reklamowych, dbających o przygotowanie materiałów promocyjno-reklamowych, wykorzystywania szerokiego spektrum narzędzi komunikacyjnych, przede wszystkim $\mathrm{z}$ obszaru marketingu politycznego, $\mathrm{z}$ dużym sukcesem stosowanych w amerykańskich kampaniach wyborczych (Plasser, 2001; Mazur, 2011; Dobek-Ostrowska, Wiszniowski, 2007; Kolczyński, 2007, s. 375; Stępińska, 2004; Mazur, 2002; Churska-Nowak, Drobczyński, 2011; Gibson, Römmele, 2001, 2009)2 ${ }^{2}$, wreszcie korzystania z całego spektrum narzędzi badawczych, umożliwiających analizę postaw i opinii wyborców (Mazur 2002). Amerykanizacja stała się więc synonimem profesjonalizacji (zob. Gurevitch, 1999, s. 281-284; Negrine, Papathanassopoulos, 1996; zob. szerzej Brodzińska-Mirowska, 2013, s. 63-103). Następstwem przyjęcia takiego spojrzenia jest: 1) utożsamianie profesjonalizacji kampanii wyborczych z procesem profesjonalizacji komunikacji politycznej w ogóle, 2) traktowanie amerykanizacji jako synonimu profesjonalizacji i wreszcie 3) mediacentryczność, czyli traktowanie medialnego wymiaru

1 Jak podkreślają Karen Sanders i współpracownicy, koncepcja profesjonalizacji związana jest ściśle z socjologią pracy. Chociaż, jak zauważają badacze, bardzo trudno jest jednoznacznie wskazać, od kiedy określamy kampanie wyborcze mianem profesjonalnych. Nie zmienia to faktu, że profesjonalizacja jest ściśle utożsamiana właśnie z zaangażowaniem specjalistów z zakresu komunikacji w obszar działań komunikacji politycznej (Sanders i in., 2011 s. 525-526).

2 Zdaniem Gibson i Römmele profesjonalizacja komunikacji politycznej doprowadziła do sytuacji, w której partie polityczne w zasadzie nie dyskutują ze swoimi wyborcami na tematy ściśle związane z polityką, ale dyskutują na temat swojego produktu, co zdaniem przytaczanych autorek prowadzi do sytuacji, w której lojalnego zwolennika zastąpił konsument (Gibson, Römmele 2001, s. 32). 
działań komunikacyjnych (w tym wykorzystania narzędzi ICT) jako głównego kryterium profesjonalizacji (por. Brodzińska-Mirowska, 2014, 2018) (schemat 1).

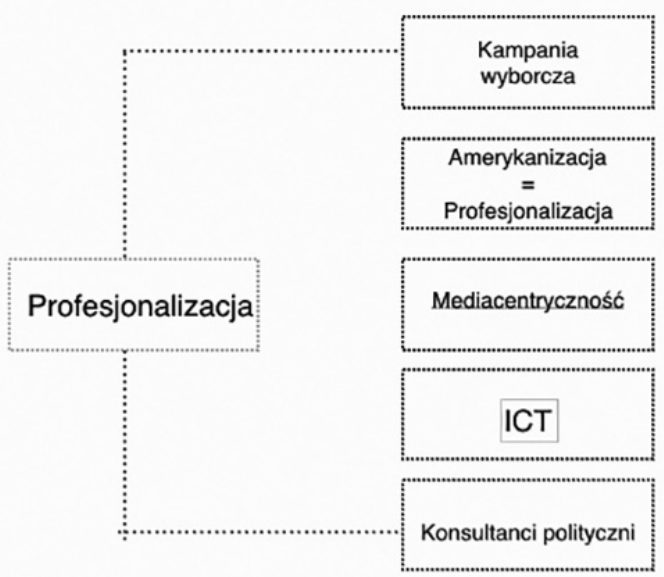

Schemat 1. Dotychczasowe spojrzenie na proces profesjonalizacji komunikacji politycznej

Źródło: opracowanie własne.

Od połowy pierwszej dekady XXI wieku pojawiły się nieco inne ujęcia i spojrzenia na komunikację polityczną, w tym na profesjonalizację. W celach systematyzujących dorobek badawczy w tym zakresie określam ten okres postamerykanizacyjnym. Coraz częściej profesjonalizacja zaczyna być wówczas ujmowana jako przejaw szerszego procesu zmian społecznych, zaś odnośnie samego procesu komunikacji akcentuje się konieczność strategicznego podejścia, a więc uwzględnia się także okres międzywyborczy. Innymi słowy, na poziomie teoretycznych rozważań badacze wykraczają poza wymiar wyborczy i związany wyłącznie $\mathrm{z}$ aktywnością na poziomie medialnym. W perspektywie postamerykanizacyjnej nie chodzi o ocenę podobieństwa do praktyk amerykańskich czy skalę zastosowanych technik, choć oczywiście mogą być one pewnym wskaźnikiem, ale o ocenę specyfiki procesu, który zachodzi w konkretnym otoczeniu społeczno-politycznym i kulturowym (Pfetsch, Esser, 2004; Nielsen, 2014, s. 5-22; Brodzińska-Mirowska, 2013; Mazur, 2011; Nord, 2001, 2006; Negrine, 2008, s. 152-157; Holtz-Bacha, 2007, s. 63-79).

Mediatyzacja zmienia nie tylko sposób uprawiania polityki, ale także zmienia reguły komunikacji politycznej, które podporządkowują się logikom medialnym 
(Mazzoleni, Schulz, 1999; Strömback, 2008, 2009, 2011; Hess, 2010)³. Dotarcie do wyborców z ważnym dla partii przekazem bywa poważnym wyzwaniem, zaś agendę tematyczną dyktują cele krótkoterminowe. Mediatyzacja niesie za sobą także szereg konsekwencji, m.in. tabloidyzację, zorientowanie na konflikt, a także negatywizm w przekazach dotyczących polityki (zob. Vliegenthart i in., 2011). Jednak te i wiele innych konsekwencji powoduje, że konieczne jest wielowymiarowe spojrzenie na sam proces komunikacji politycznej, w tym także na profesjonalizację, co wydaje się jednym z najtrudniejszych zadań, przed którymi stają aktorzy polityczni.

Dlatego na proces profesjonalizacji będę patrzyła z perspektywy strategicznego podejścia do aktywności komunikacyjnej. W strategicznym rozumieniu profesjonalizacji należy uwzględniać, na ile proces kształtowania komunikacji w obszarze działań wewnętrznych i zewnętrznych ma charakter planowany, poprzedzony pogłębionymi i wielowymiarowymi analizami (Wojcik, 2015; zob. Brodzińska-Mirowska, 2018; por. Wincławska, Brodzińska-Mirowska, 2016, s. 34-37) ${ }^{4}$. Strategiczne rozumienie profesjonalizacji wpisuje się zatem w rynkową orientację podmiotów politycznych ${ }^{5}$. Profesjonalizację komunikacji politycznej będę rozumiała „jako proces obejmujący wiele płaszczyzn komunikacyjnych, manifestujący się nie tylko w wymiarze efektów, ale także organizacji komunikacji, dotyczący aktywności zarówno w okresie wyborczym, jak i międzywyborczym, znajdujący odzwierciedlenie w ciągłym doskonaleniu i rozwijaniu działań zmierzających do jak najpełniejszego wykorzystania wszelkich dostępnych zasobów organizacji politycznych w celu realizacji celów komunikacyjnych, a za ich pośrednictwem także politycznych” (por. Brodzińska-Mirowska, 2013, s. 73-74). Konsekwencją przyjęcia takiego rozumienia profesjonalizacji jest

3 Wobec bardzo dużej dywersyfikacji mediów i specyfiki ich działania, zwłaszcza w kontekście rozwoju technologicznego badacze sugerują stosowanie liczby mnogiej (zob. Meyen i in., 2014;

Hepp, 2012).

4 W strategicznym myśleniu o komunikacji szczególne znaczenie mają działania z zakresu public relations, które w rozumieniu Jamesa Gruniga mają zastosowanie w procesie zarządzania komunikacją organizacji, a więc wdrażaniem rozwiązań komunikacyjnych, które sprzyjają działaniu całej organizacji i realizacji jej celów dzięki wykorzystaniu dostępnych zasobów (Grunig, 2009, s. 4, 2011, s. 13; zob. także Mazur, 2005, s. 103-113).

5 Orientacja rynkowa zakłada zwracanie uwagi także na wewnętrzne funkcjonowanie organizacji politycznych, zwłaszcza zaś znajomość potrzeb i oczekiwań ważnych dla organizacji grup (Ormrod, Savigny 2011, s. 489). Wymogi orientacji organizacji partyjnej w kierunku rynku politycznego (PMO - ang. political market orientation), o których piszą Ormond i Savigny (przynajmniej na poziomie założeń normatywnych), znajdują zastosowanie zarówno w okresie kampanii wyborczej, jak i w okresie międzywyborczym. 
to, że za jej przejaw mogą być uznane zarówno efekty medialne, tj. spójność wizerunkowa, zadowalająca dla partii widzialność medialna, przebieg kampanii wyborczej, dzięki któremu partia realizuje swoje cele, ale także aktywność komunikacyjna prowadzona między wyborami, a wykraczająca poza relacje z mediami, czy wreszcie profesjonalna komunikacja prowadzona w sytuacji kryzysu wizerunkowego (Brodzińska-Mirowska, 2018, s. 39-63).

\section{PRÓBY OBIEKTYWIZOWANIA I MIERZENIA PROFESJONALIZACJI KOMUNIKACJI POLITYCZNEJ}

W literaturze przedmiotu znajdziemy kilka przykładów analiz, w ramach których badawcze podjęli próbę ustrukturyzowania badania procesu profesjonalizacji. Są one ważnym głosem w dyskusji na temat komunikacji politycznej, a ponadto są użyteczne w poszukiwaniu kolejnych propozycji badań profesjonalizacji. Najbardziej znaną propozycją analizy procesu profesjonalizacji jest Indeks Camprof, zaproponowany przez Rachel Gibson oraz Andreę Römmele (2009, s. 265-293). Autorki koncentrują się przede wszystkim na wykorzystanych narzędziach komunikacyjnych oraz współpracy ze specjalistami. Analizują one profesjonalizację przez pryzmat kampanii wyborczej. Propozycja Römmele i Gibson nie jest wolna od pewnych nieścisłości, szczególnie w zakresie wprowadzenia kategorii kampanii permanentnej w obszar oceny profesjonalizacji kampanii wyborczej (Brodzińska-Mirowska, 2013; Sanders i in., 2011, s. 526). Należy jednak podkreślić, że propozycja autorek nie tylko stała się inspiracją dla wielu badaczy, którzy zaproponowali zmodyfikowane i często niezwykle zaawansowane narzędzia analizy procesu profesjonalizacji komunikacji wyborczej (zob. Tenscher i in., 2012 s. 145-168; Strömback, 2009) ${ }^{6}$, ale przede wszystkim zwróciła uwagę na

6 Jens Teschner, Juri Mykkänen i Tom Moring w analizach, których przedmiotem był przebieg kampanii wyborczych do Parlamentu Europejskiego, poszerzają i pogłębiają indeks oceniający poziom profesjonalizacji kampanii. Jako największą słabość dotychczasowych ujęć kampanii Teschner, wraz ze współpracownikami, wskazują koncentrację na strukturze kampanii, z pominięciem kwestii badania strategii. Jak podkreślają: "struktura odzwierciedla organizacyjne warunki kampanii, jest swoistym »hardware " podczas gdy strategiczne prowadzenie kampanii stanowi kampanijny »software «” (Teschner i in., 2012, s. 149). W związku z tym w zaproponowanym przez siebie modelu analizy profesjonalizacji wyszczególniają dwa poziomy 1) struktura kampanii i 2) strategia kampanii. Na pierwszym poziomie analizy wyróżniają osiem wskaźników z maksymalną liczbą 24 punktów (liczba członków sztabów, poziom centralizacji w zakresie organizacyjnym, outsourcing niektórych zadań na zewnątrz sztabu, współpraca $\mathrm{z}$ agencjami reklamowymi, narzędzia wykorzystywane do prowa- 
konieczność badania i mierzenia profesjonalizacji. Tym bardziej że przyjmowanie a priori faktu, że proces ten zachodzi, jest dużym uproszczeniem, zwłaszcza że praktyka społeczna pokazuje, że zachodzi nie zawsze i nie we wszystkim przypadkach w takich samym zakresie (Strömback, 2009, s. 95-116; Nord, 2001, 2006; Brodzińska-Mirowska, 2013). Z uwagi na szereg czynników determinujących ten proces (Gibson, Römmele, 2001) nie jest to wcale zaskakujące.

Komunikowanie polityczne to nie tylko kwestia kampanii wyborczej, zaś profesjonalizacja kampanii wyborczej nie jest, rzecz jasna, równoznaczna z profesjonalizacją komunikacji także w okresie międzywyborczym (zob. Brodzińska-Mirowska, 2013; Sanders i in., 2011, s. 524). Profesjonalizacja w kontekście permanentnych działań komunikacyjnych jest omawiana w literaturze rzadko, a próby ustrukturyzowanych badań komunikacji międzywyborczej najczęściej dotyczą komunikacji rządowej (Sanders, Canel, 2013; Sanders, Canel, 2012; Sanders, Crespo, Holtz-Bacha, 2011, s. 523-547; Sanders, 2011; Horsley i in., 2010; Kasińska-Metryka, 2007; Anaszewicz, 2015). Na kanwie dotychczasowych rozważań chciałabym zaproponować jeszcze inne spojrzenie na proces profesjonalizacji. Efektywne działanie komunikacyjne zarówno w okresie kampanii wyborczej, jak i komunikacji międzywyborczej wymaga spojrzenia na proces profesjonalizacji od podstaw.

dzenia działań mobilizacyjnych wobec członków partii: analizy i badania w celu uzyskania feedbacku, analiza konkurencji, czas implementacji działań). Na poziomie strategii wyszczególnili siedem wskaźników, z maksymalną liczbą 26 punktów. Na tym poziomie skupili się przede wszystkim nad wyborem poszczególnych kanałów dystrybucji przekazu; są to: skala targetowania przekazów, skala podejmowanych bezpośrednich działań komunikacyjnych z grupami docelowymi, ocena wartości, jaką mają dla kampanii płatne przekazy, np. reklamy, ocena wartości dla kampanii poszczególnych mediów, np. krajowych, lokalnych czy też tabloidów, ocena relewancji udziału kandydatów w formatach typu talk show, ocena poziomu orientacji sztabów na organizację eventów pod kątem oczekiwań mediów, poziom personalizacji) (Teschner i in., 2012, s. 145-168). Zatem, jak widać, skala oceny była bardzo szczegółowa. Jak każde narzędzie, także i to budzić może pewne zastrzeżenia. Nie ma tu miejsca na szerszą dyskusję i polemikę, podkreślę tylko, że największe wątpliwości budzi poziom strategiczny. Oczywiście wskaźniki wyszczególnione przez autorów są interesujące i ocena ich zakresu i znaczenia jest $\mathrm{z}$ badawczego punktu widzenia wiedzą bardzo istotną, jednak tak zaprezentowane ujęcie poddaje ocenie raczej taktykę niż strategię. 


\section{INDEKS PROFESJONALIZACJI KOMUNIKACJI POLITYCZNEJ}

Poniższa propozycja zakłada przede wszystkim analizę tego, jak wygląda proces organizacji komunikacji. Umożliwia odpowiedź na pytanie, na ile wdrażane działania mają charakter zaplanowany, powtarzalny, poddawany ewaluacji słowem: strategiczny. W związku z powyższym wyróżniam kilka płaszczyzn oceny zakresu profesjonalizacji: 1) organizacyjną, 2) strategiczną, 3) medialną i 4) technologiczną ${ }^{7}$. Do każdej z nich przyporządkowane zostały poszczególne aktywności, które, w mojej ocenie, są wskaźnikiem profesjonalnego podejścia do działań komunikacyjnych, bez względu na to, czy są podejmowane w okresie kampanii wyborczej, czy poza nią. W proponowanej koncepcji analizy procesu profesjonalizacji będę uwzględniała wskaźniki, które dają pogląd m.in. na to, czy organizacje partyjne uwzględniają wielowymiarowość działań komunikacyjnych, a w dalszej kolejności także, czy wykorzystują wszystkie swoje zasoby, w tym ludzkie i organizacyjne (zob. Wincławska, Brodzińska-Mirowska, 2016), i czy dominuje w tym podejściu perspektywa strategicznego podejścia do komunikacji (Kolczyński, 2007). W kontekście dotychczasowych analiz wnioskuję, że w zakresie komunikacji politycznej, zwłaszcza zaś profesjonalizacji, warto w pierwszej kolejności poddawać analizie fundamentalne, najbardziej podstawowe, aczkolwiek determinujące działania i aktywności, zwiększające efektywność w zakresie komunikacji.

Szczegóły proponowanego modelu przedstawiam w tabeli 1.

Tabela 1. Indeks profesjonalizacji komunikacji politycznej

\begin{tabular}{|c|c|}
\hline Wymiar organizacyjny & Skala punktowa \\
\hline $\begin{array}{l}\text { 1. Program ustrukturyzowanych działań komunikacji wewnętrznej (z człon- } \\
\text { kami, strukturami) } \\
\text { - spotkania bezpośrednie liderów partyjnych w terenie w roku niewybor- } \\
\text { czym (partia rządząca - min. } 7 \text { rocznie - } 1 \text { p, partia opozycyjna min. } 10 \\
\text { rocznie - 1p) } \\
\text { - materiały prasowe, opracowania merytoryczne, informacje nt. spraw } \\
\text { partyjnych skierowane wyłącznie do członków } \\
\text { - wewnątrzpartyjne wydawnictwa skierowane do wyborców, sympatyków } \\
\text { (online/offline) }\end{array}$ & $\begin{array}{l}0-1 \\
0-1\end{array}$ \\
\hline
\end{tabular}

$7 \quad$ W ramach pierwszych prób operacjonalizacji pojęcia profesjonalizacji wyszczególniałam nieco inne jej wymiary, tzn. organizacyjny, medialny, technologiczny, marketingowy oraz zasobów ludzkich (por. Brodzińska-Mirowska, 2013, s. 74). 


\begin{tabular}{|c|c|}
\hline Wymiar organizacyjny - cd. & Skala punktowa \\
\hline $\begin{array}{l}\text { 2. Badania opinii członków na temat partii, programu lub kwestii ważnych } \\
\text { dla partii (min. } 1 \mathrm{w} \text { kadencji - } 1 \text { p., więcej niż } 1 \mathrm{w} \text { kadencji }-2 \mathrm{p} \text { ) }\end{array}$ & $0-2$ \\
\hline $\begin{array}{l}\text { 3. Badania opinii pracowników administracyjnych partii z regionów na temat } \\
\text { organizacji pracy partii lub ważnych dla partii problemów organizacyjnych } \\
\text { (min. } 1 \text { w kadencji) (1p.) }\end{array}$ & $0-1$ \\
\hline $\begin{array}{l}\text { 4. Obligatoryjne działania komunikacyjne obowiązujące w partii w zakresie } \\
\text { liczby konferencji prasowych, spotkań bezpośrednich, eventów w regionach }\end{array}$ & $0-1$ \\
\hline $\begin{array}{l}\text { 5. Prowadzony z poziomu centralnych struktur partii monitoring działań } \\
\text { komunikacyjnych prowadzonych przez niższe struktury organizacyjne } \\
\text { (w systemie kwartalnym) }\end{array}$ & $0-1$ \\
\hline $\begin{array}{l}\text { 6. Współpraca partii na poziomie centralnym z partią na poziomie regional- } \\
\text { nym w zakresie know-how (tzn. szkolenia z zakresu komunikacji w różnych } \\
\text { obszarach, udzielania wsparcia organizacyjnego strukturom niższego } \\
\text { szczebla w realizacji inicjatyw w regionie m.in. } 1 \text { rocznie) }\end{array}$ & $0-1$ \\
\hline $\begin{array}{l}\text { 7. Zespół osób/osoba/jednostka odpowiedzialna za integrowania działań } \\
\text { komunikacyjnych całej partii zarówno w wymiarze wewnętrznym, jak } \\
\text { i zewnętrznym }\end{array}$ & $0-1$ \\
\hline $\begin{array}{l}\text { 8.Min. jedna osoba w zespole w centralnym biurze administracyjnym partii } \\
\text { odpowiedzialnym za komunikację posiada doświadczenie w pracy w ob- } \\
\text { szarze komunikacji (marketing, public relations) lub wykształcenie z tego } \\
\text { obszaru (1p.) }\end{array}$ & $0-1$ \\
\hline \multirow[t]{2}{*}{$\begin{array}{l}\text { 9. Organizacja szkoleń z zakresu komunikacji z wyborcami, komunikacji } \\
\text { z mediami, organizacji konferencji prasowych dla posłów (min. } 1 \text { w kadencji) }\end{array}$} & $0-1$ \\
\hline & max. punktów 12 \\
\hline Wymiar strategiczny & Skala punktowa \\
\hline $\begin{array}{l}\text { 1. Funkcjonowanie w ramach partii stałego zespołu osób zajmujących się } \\
\text { komunikacją i wizerunkiem partii i jej liderów }\end{array}$ & $0-1$ \\
\hline $\begin{array}{l}\text { 2. Praktyka współpracy z ekspertami zewnętrznymi ds. komunikacji } \\
\text { w systemie działań wyborczych: konsultacyjna rola specjalisty (1p.), szkolenie } \\
\text { dotyczące komunikacji dla sztabu wyborczego (1p), opracowanie strategii } \\
\text { komunikacyjnej (1p), koordynacja wdrażania strategii (1p.) }\end{array}$ & $0-4$ \\
\hline $\begin{array}{l}\text { 3. Praktyka współpracy z ekspertami zewnętrznymi ds. komunikacji w syste- } \\
\text { mie działań międzywyborczych: min. } 2 \text { konsultacje rocznie odnośnie strategii } \\
\text { komunikacyjnej (1p.), wsparcie w sytuacjach kryzysu komunikacyjnego lub } \\
\text { wizerunkowego (1p.) }\end{array}$ & $0-2$ \\
\hline $\begin{array}{l}\text { 4. Badania opinii publicznej na użytek wewnętrzny partii (min. } 1 \text { w roku, } \\
\text { więcej niż raz w roku - 2p) }\end{array}$ & $0-2$ \\
\hline $\begin{array}{l}\text { 5. Analizy powyborcze (na podstawie badań własnych lub na podstawie } \\
\text { danych zastanych) elektoratu (mapping kto, jak i dlaczego głosował) }\end{array}$ & $0-1$ \\
\hline 6. Badania wizerunkowe partii (min. $1 \mathrm{w}$ kadencji) & $0-1$ \\
\hline
\end{tabular}




\begin{tabular}{|c|c|}
\hline Wymiar strategiczny - cd. & Skala punktowa \\
\hline $\begin{array}{l}\text { 7. Ogólna strategia komunikacyjna dla całej organizacji (zawierająca główne } \\
\text { przekazy, grupy docelowe, główne wartości prezentowane przez partię) }\end{array}$ & $0-1$ \\
\hline $\begin{array}{l}\text { 8. Strategie szczegółowe dotyczące konkretnych zmian/ reform (w przypadku } \\
\text { partii rządzącej) lub propozycji zmian lub wizji (partia opozycyjna) }\end{array}$ & $0-2$ \\
\hline \multirow{2}{*}{$\begin{array}{l}\text { 9. Prowadzenie ewaluacji (ocena efektów) działań komunikacyjnych (po } \\
\text { kampanii wyborczej) (1p), po każdej kampanii informacyjnej (1p) }\end{array}$} & $0-2$ \\
\hline & max. punktów 16 \\
\hline Wymiar medialny & Skala punktowa \\
\hline $\begin{array}{l}\text { 1. Funkcjonowania biura prasowego partii (rzecznik prasowy plus min. } 1 \\
\text { osoba) }\end{array}$ & $0-1$ \\
\hline $\begin{array}{l}\text { 2. Funkcjonowanie } \mathrm{w} \text { ramach biur regionalnych jednostek/osób odpowie- } \\
\text { dzialnych za relacje z mediami }\end{array}$ & $0-1$ \\
\hline 3. Prowadzenie biura prasowego (online) & $\mathbf{0}-1$ \\
\hline $\begin{array}{l}\text { 4. Współpraca z ekspertami z zewnątrz w zakresie komunikacji medialnej } \\
\text { (m.in. } 1 \text { konsultacja rocznie). }\end{array}$ & $0-1$ \\
\hline $\begin{array}{l}\text { 5. Stały monitoring mediów (w kampanii wyborczej - } 1 \text { p; w okresie } \\
\text { międzywyborczym } 1 \mathrm{p} \text { ) }\end{array}$ & $0-2$ \\
\hline 6. Przekazy dnia (dla parlamentarzystów) & $0-1$ \\
\hline \multirow[t]{2}{*}{$\begin{array}{l}\text { 7. Min. } 1 \text { pracownik biura prasowego z doświadczeniem pracy z mediami ( } \\
\text { w mediach) lub z wykształceniem w obszarze komunikacji }\end{array}$} & $0-1$ \\
\hline & max. punktów 8 \\
\hline Wymiar ICT & Skala punktowa \\
\hline 1. Strona internetowa partii & $0-1$ \\
\hline 2. Stały monitoring Internetu & $0-1$ \\
\hline $\begin{array}{l}\text { 3. Dodatkowe platformy dedykowane konkretnym projektom realizowanym } \\
\text { przez partie m.in. } 1 \mathrm{w} \text { ostatnim roku }\end{array}$ & $0-1$ \\
\hline $\begin{array}{l}\text { 4. Systematyczne prowadzeniu profilu na portalu/portalach społecznościo- } \\
\text { wych ( min. } 1 \text { portal i min. } 3 \text { wpisy w tygodniu) }\end{array}$ & $0-1$ \\
\hline 5. Intranet/grupy dyskusyjne w ramach komunikacji wewnętrznej & $0-1$ \\
\hline 6. Newslettery (wysyłka m.in. 2 razy w miesiącu) & $0-1$ \\
\hline 7. Transmisje na żywo ważnych wydarzeń partyjnych & $0-1$ \\
\hline \multirow[t]{2}{*}{ 8. Jednostka/zespół osób/osoba odpowiedzialna za komunikację online } & $0-1$ \\
\hline & max. punktów 8 \\
\hline Suma całość & 44 punktów \\
\hline
\end{tabular}

Źródło: opracowanie własne. 
Głównym założeniem, leżącym u podstaw tej propozycji, była możliwość prześledzenia procesu zarządzania komunikacją, szczególnie, że efekty komunikacyjne zwykle analizowane są w kontekście case study. Bardzo często to właśnie na poziomie organizacji, planowania i wdrażania działań komunikacyjnych upatruje się przyczyn niepowodzeń w zakresie komunikacji międzywyborczej, a w konsekwencji także wyborczej (zob. Brodzińska-Mirowska, 2018; Drobczyński, 2011). Propozycja ta wychodzi tym samym poza techniczną, zewnętrzną i wyborczą analizę efektów działań komunikacyjnych. Badania profesjonalizacji mają na celu przede wszystkim analizę tego, $\mathrm{w}$ jakim zakresie partia polityczna korzysta z organizacyjnego potencjału, jaki posiada (Wincławska, Brodzińska-Mirowska, 2016; Brodzińska-Mirowska, Wincławska, 2018), szczególnie przy założeniu, że rynek profesjonalnego wsparcia zewnętrznego w zakresie komunikacji politycznej zasadniczo różni się od rynku konsultantów politycznych znanego z doświadczeń amerykańskich. I tak profesjonalizacja w wymiarze organizacyjnym jest podstawowym elementem wspierającym i zwiększającym skuteczność zarówno w komunikacji wewnętrznej, jak i zewnętrznej. Wielowymiarowa komunikacyjna uwzględniająca także stały kontakt z członkami partii, jej sympatykami, i wyborcami jest koniecznością w dobie mediatyzacji, gdzie reguły funkcjonowania mediów utrudniają kontrolowanie przekazu zgodnie z intencjami nadawców/aktorów politycznych.

W przypadku profesjonalizacji komunikacji w wymiarze strategicznym celem jest odpowiedź na pytanie o zakres, w jakim partie polityczne opierają swoje decyzje komunikacyjne - a co za tym idzie, całościowe strategie wizerunkowe, a także działania taktyczne - na gruntownych i miarodajnych analizach. W jakim stopniu działaniom merytorycznym towarzyszą planowane i przemyślane $\mathrm{w}$ ramach organizacji działania komunikacyjne, czy wreszcie jaki jest charakter wsparcia, udzielany partiom politycznym przez ekspertów ds. komunikacyjnych. Natomiast profesjonalizacja organizacji komunikacji w wymiarze medialnym oraz związana $\mathrm{z}$ nowymi technologiami w założeniu ma dać wgląd $\mathrm{w}$ to, jakie działania podejmuje partia celem maksymalizacji efektów komunikacyjnych w tych obszarach.

W przypadku podejmowania aktywności w wyszczególnionych wymiarach przyporządkowałam określoną skalę punktową od 0 do maksymalnie 4 punktów, zaznaczając minimalne progi dla niektórych aktywności. $Z$ uwagi na specyfikę komunikacji w przypadku partii rządzących i opozycyjnych przy niektórych wskaźnikach wprowadzam to rozróżnienie. Organizacja może uzyskać maksymalnie 44 punkty. Zakładam przy tym, że z uwagi na różnorodne zasoby orga- 
nizacji partyjnych proces profesjonalizacji zachodzi nierównomiernie. Dlatego wyszczególniam dwa poziomy profesjonalizacji: 1) poziom profesjonalizacji zrównoważonej, o której mówimy w sytuacji, w której organizacja polityczna uzyskuje co najmniej połowę maksymalnej liczby punktów w wyszczególnionych wymiarach, lub 2) profesjonalizacji selektywnej, o której będziemy mówić w sytuacji, w której np. w jednej płaszczyźnie organizacja uzyska wynik maksymalny, natomiast w innych nie uzyska połowy maksymalnej liczby punktów. Strukturyzacja badania profesjonalizacji pozwala stosować takie same wskaźniki oceny zarówno dla partii rządzącej, jak i opozycyjnej, z zastrzeżeniem, że w przypadku partii rządzącej poddajemy analizie partię, a nie działania rządu. Badania porównawcze dają możliwość ewaluacji rozwoju danego podmiotu politycznego w obszarze komunikacji na przestrzeni dłuższego czasu. Powtarzalność badania w przypadku zaobserwowania profesjonalizacji selektywnej pozwala sprawdzić, czy nastąpiło pełne sprofesjonalizowanie lub w przypadku profesjonalizacji zrównoważonej, czy poziom jest utrzymany. Taka analiza daje wgląd w zakres zmian, jakie zachodzą w przedmiotowym obszarze w wyniku utraty lub zdobycia władzy przez partię albo z uwagi na „cykl życia” produktu politycznego. Występujące między partiami politycznymi różnice mogłyby dawać wgląd w to, jakie partia podejmuje działania w przypadku znaczących ograniczeń (budżetowych i ludzkich). Analizy w proponowanym wymiarze mogą dać także obraz tego, na jakie działania partie kładą nacisk i czy te aktywności wpisują się w działania, które można nazywać profesjonalnymi i strategicznymi. Przedstawiona propozycja ma wreszcie na celu uchwycenie kwestii newralgicznych dla badań komunikacji politycznej. Mowa przykładowo o: 1) współpracy ze specjalistami z zewnątrz, 2) wykorzystaniu zasobów organizacyjnych zarówno w okresie wyborczym, jak i międzywyborczym, a więc kwestiach będących elementem rzadko badanej 3) komunikacji wewnętrznej (zob. Wincławska, Brodzińska-Mirowska, 2016; Brodzińska-Mirowska, Wincławska, 2018).

8 Na zagadnienie selektywności procesu profesjonalizacji, ale w kontekście kampanii wyborczej zwraca uwagę w swoich analizach także Strömbäck (2009). 


\section{WYZWANIA I OGRANICZENIA BADAWCZE: DYSKUSJA}

Fundamentalne wyzwania koncepcyjne w zakresie badania profesjonalizacji, tak jak starałam się ukazać w pierwszej części artykułu, związane są przede wszystkim z samym pojęciem, czyli z odpowiedzią na pytanie, jak rozumiemy profesjonalizację komunikacji politycznej i gdzie poszukujemy jej manifestacji, szczególnie w dobie intensyfikacji takich zjawisk, jak coraz mniejsze zaufanie do polityki z jednej strony, a narastający problem fake newsów czy zagrożeń, jakie niosą dla procesów politycznych nowe media, po reaktywację propagandowych form aktywności komunikacyjnej z drugiej strony. To z kolei wiąże się z wyzwaniami badawczymi. Z uwagi na to, że komunikacja polityczna jest zjawiskiem wieloaspektowym i złożonym, a priori należy przyjąć konieczność projektowania wielu narzędzi dostosowanych do precyzyjnie określonego obszaru badań profesjonalizacji. Wypracowanie jednego narzędzia badawczego, za pomocą którego można dokonać gruntownej oceny zakresu profesjonalizacji komunikacji politycznej rozumianej całościowo, jest niezwykle trudne. Analiza poszczególnych wymiarów, nawet przy dostosowaniu narzędzi w zależności od badanego obszaru, mogłaby dać pełniejszy ogląd całego procesu. Warunku tego nie wypełniają analizy profesjonalizacji wyłącznie w zakresie kampanii wyborczych. Elementem łączącym złożone analizy, np. profesjonalizacji komunikacji kryzysowej w polityce czy profesjonalizacji w zakresie media relations lub w obszarze komunikacji rządowej mogłoby być porządkowanie według zaproponowanych kategorii oceny: profesjonalizacji zrównoważonej i selektywnej.

Kolejny element, który przy badaniach profesjonalizacji komunikacji politycznej może być problematyczny, to kwestia wskaźników. Przy czym nie chodzi li tylko o ich wybór, tzn. jakie elementy uwzględnić przy badaniu poszczególnych obszarów, a jakie nie, ale o kwestię dostosowania wskaźników do realnych możliwości ich zastosowania przez organizacje partyjne. Wyzwaniem może być selekcja związana z tym, że na obszar komunikacji politycznej przykładana jest często swego rodzaju kalka aktywności komunikacyjnej podejmowanej przez podmioty komercyjne. Trudność polega zatem na zachowaniu elementarnych ram, bez których trudno osiągnąć podstawowe cele komunikacyjne także w sferze politycznej, jednak z uwzględnieniem specyfiki materii, która jest badana. 


\section{PODSUMOWANIE}

Celem powyższych rozważań było podjęcie dyskusji i refleksji nad samym procesem profesjonalizacji już na etapie jej planowania i kształtowania. Jest to zadanie szczególnie istotne z punktu widzenia wyzwań komunikacyjnych, z którymi muszą się mierzyć aktorzy polityczni w dobie mediatyzacji. Powyższa propozycja jest próbą zwrócenia uwagi na konieczność wieloaspektowego i różnorodnego podejścia do zjawiska profesjonalizacji, ale także refleksji nad złożoną i problematyczną materią, jaką są analizy profesjonalizacji komunikacji politycznej. Pogłębiona refleksja nad procesem profesjonalizacji komunikacji politycznej rodzi szereg pytań i wyzwań. Przykładowo, czy proces profesjonalizacji rozumianej jako strategiczne podejście do komunikacji w dobie mediatyzacji jest w przypadku organizacji partyjnych w ogóle możliwy? Czy wymagania w zakresie profesjonalizacji z silnie komercyjnymi konotacjami mają rację bytu $\mathrm{w}$ otoczeniu politycznym? Jak w dobie mediatyzacji, a więc konieczności adaptacji aktorów politycznych do zasad i potrzeb mediów, partie polityczne radzą sobie $\mathrm{z}$ wielowymiarową komunikacją, w tym komunikacją międzywyborczą? W jaki sposób włączyć w proces badania profesjonalizacji kwestię podejmowania decyzji dotyczących komunikacji, który jest istotny dla całego procesu, a jednocześnie mógłby ukazać np. rolę specjalistów z zakresu komunikacji w procesie jej kształtowania? Badania profesjonalizacji, zwłaszcza w szerszym rozumieniu, są godne uwagi i dalszych prac teoretycznych, metodologicznych i empirycznych. Wielopłaszczyznowe badania profesjonalizacji komunikacji politycznej dają wgląd w to, jak proces ten jest kształtowany, jaka jest jego specyfika w konkretnych kontekstach społecznych i politycznych.

\section{BibLIOGRAFIA:}

Anaszewicz, M.(2015). Komunikowanie rzadowe w Polsce. Perspektywa instytucjonalna. Wrocław: Wydawnictwo Uniwersytetu Wrocławskiego.

Blumler, J., Gurevitch, M. (1995). The Crisis of Public Communication. New York: Routladge.

Brodzińska-Mirowska, B. (2013). Marketing międzywyborczy w teorii i praktyce. Przypadek Platformy Obywatelskiej. Toruń: UMK. Brodzińska-Mirowska, B. (2014). Unfulfilled Expectations (?): Political Communication on the Internet in the Era of Professionalization. E-politicon, 9, 43-64.

Brodzińska-Mirowska, B. (2018) Porażka wyborcza w dobie profesjonalizacji: o konieczności zmiany perspektywy w komunikowaniu politycznym. W: A. Pacześniak (red.). Anatomia porażki (s. 39-63). Warszawa: Wydawnictwo Sejmowe. 
Brodzińska-Mirowska, B., Wincławska, M. (2018). Partie polityczne w dobie wyzwań w obszarze komunikacji. Wewnętrzna komunikacja polityczna w perspektywie członków ugrupowań partyjnych. W: A. Bąk-Szołucha, Ł. Kubisz-Muła (red.). Oblicza komunikacji. Polityka, intytucje publiczne, biznes (s. 47-65). Bielsko-Biała: Wydawnictwo Naukowe ATH.

Churska-Nowak, K., Drobczyński, S. (red). (2011). Profesjonalizacja i mediatyzacja kampanii wyborczych. Poznań: WSNHiD.

Dobek-Ostrowska, B., Wiszniowski, R. (2007). Teoria komunikowania publicznego i politycznego. Wrocław: Astrum.

Drobczyński, S. (2011). Przyczyny klęsk wyborczych - błędy popełniane podczas organizacji i prowadzenia kampanii wyborczych w Polsce. W: K. Churska-Nowak, S. Drobczyński (red.) Profesjonalizacja i mediatyzacja kampanii wyborczych (s. 107-144). Poznań: WSNHiD.

Gibson, R., Römmele, A. (2001). Changing Campaign Communications: A Party-Centered Theory of Professionalized Campaigning. The Harvard International Journal of Press/Politics, 6(4), 31-43. DOI: 10.1177/108118001129172323.

Gibson, R., Römmele, A.(2009). Measuring the Professionalization of Political Campaigning. Party Politics, 15(3), 265-293. DOI: 10.1177/1354068809102245.

Green D.P., Smith J.K. (2003). Professionalization of Campaigns and the Secret History of Collective Action Problems. Journal of Theoretical Politics, 15(3), 321-339. DOI: 10.1177/2F0951692803015003005.

Gurevitch, M. (1999). Whither the Future? Some Afterthoughts. Political Communication, 16(3), 281-284.

Grunig, J. (2009). Paradigms of Global Public Relations in an Age of Digitalization, PRism, 6(2). Pobrane z: http://www.prismjournal.org/fileadmin/Praxis/Files/ globalPR/GRUNIG.pdf.

Grunig, J. (2011). Public Relations and Strategic Management. Institutionalizing Organization - Public Relationship in Contemporary Society. Central European Journal of Communication, 1, 11-31.

Hepp, A. (2012). Mediatization and the 'Molding Force' of the Media. Communication, 37(1), 1-28. DOI: 10.1515/commun-2012-0001.

Hess, A. (2010). Relacje mediów masowych i partii politycznych jako przedmiot badań studiów nad komunikowaniem politycznym - wprowadzenie. W: K. Sobolewska-Myślik, A. Hess, K. Kowalczyk (red.). Polska Scena Polityczna. Środowiska - komunikacja polityczna - strategie (s. 131-140). Kraków: Wydawnictwo Uniwersytetu Jagiellońskiego, Wydawnictwo Uniwersytetu Pedagogicznego.

Horsley, S., Fisher Liu, B., Levenshus, A.B. (2010). Comparisons of U.S. Government Communication Practices: Expanding the Government Communication Decision Wheel. Communication Theory, 20, 269-295. DOI:10.1111/j.14682885.2010.01363.x.

Holtz-Bacha, Ch. (2007). Professionalisation in Politics in German. W: R. Negrine, P. Mancini, Ch. Holtz-Bacha, S. Papathanassopoulos (red.). The Professionalization 
of political communication. Changing Media, Changing Europe (s. 63-79). Bristol UK/Chicago USA: Intelect.

Kasińska-Metryka, A. (2007). Marketing międzywyborczy w praktyce. Sto dni rządu Kazimierza Marcinkiewicza. W: T. Soliński, D. Tworzydło, Public relations narzędzia przyszłości, (s. 99-109). Rzeszów: Wydawnictwo WSiZ.

Kolczyński, M. (2007). Strategie komunikowania politycznego. Katowice: Wydawnictwo Uniwersytetu Śląskiego.

Mancini, P. (1999). New Frontiers in Political Professionalism. Political Communication, $16,231-245$.

Mazzoleni, G., Schulz, W. (1999). Mediatization of Politics: a Challenge for Democracy?, Political Communication, 16(3), 247-261. DOI: 10.1080/105846099198613.

Mazur, M. (2002). Marketing polityczny. Studium porównawcze. PWN: Warszawa.

Mazur, M. (2005). Pułapki i błędy w praktyce politycznego public relations. W: A. Kasińska-Metryka, M. Skawińska (red.). Oblicza współczesnej polityki (s. 103-113). Kielce: Wydawnictwo Akademii Świętokrzyskiej.

Mazur, M.(2011). Amerykanizacja polskich kampanii wyborczych? W: K. Churska-Nowak, S. Drobczyński (red.). Profesjonalizacja i mediatyzacja kampanii wyborczych (s. 17-38). Poznań: WSNHiD.

Meyen, M., Thieroff, M, Strenger, S. (2014). Mass Media Logic and the Mediatization of Politics. Journalism Studies, 15(3), 271-288. DOI: 10.1080/1461670X.2014.889459.

Negrine, R. (2008). The Transformation of Political Communication. Continuties and Changes in Media and Politics. New York: Palgrave Macmillan.

Negrine, R., Papathanassopoulos, S. (1996). The "Americanization" of political communication: A Critique. The Harvard International Journal of Press/Politics, 1(2), 45-62. DOI: $10.1177 / 1081180 X 96001002005$.

Nielsen, K.N. (2014). Political Communication Research: New Media, New Challenges and New Opportunities. MedieKultur, 56, 5-22.

Nord, L. (2001). Americanization vs. the Middle Way: New Trends in Swedish Political Communication. The Harvard International Journal of Press/Politics, 6, 113-119.

Nord, L. (2006). Still the Middle Way: A study of Political Communication Practices in Swedish Election Campaigns. The Harvard International Journal of Press/Politics, 11(1), 64-76. DOI: 10.1177/1081180X05284040.

Ormrod, R., Savigny, H. (2011). Political Market Orientation: a Framework for Understanding Relationship Structures in Political Parties. Party Politics, 18(4), 487-502. DOI: $10.1177 / 1354068810389632$.

Pfetsch, B., Esser, F. (2004). Comaring Political Communication: Reorientation in a Changing World. W: B. Pfetsch, F. Esser (red.). Comparing Political Communication. Theories, Cases, and Challagnes (s. 3-22). Cambridge, New York: Cambridge University Press.

Plasser, F. (2001). Parties' Diminishing Relevance for Campaign Professionals. The Harvard International Journal of Press/Politics, 6(4), 44-59. DOI: $10.1177 / 108118001129172332$. 
Sanders, K. (2011). Political Public Relations and Government Communication. W: J. Strömback, S.Kiousis (red.). Political Public Relations. Principles and Applications (s. 254-273). New York, London: Routledge.

Sanders, K., Canel, J.M. (2012). Government Communication: an Emerging Field in Political Communication Research. W: H. Semetko, M. Scammell (red.). The Sage Handbook of Political Communication (s. 85-96). Londyn: Sage.

Sanders, K., Crespo-Canel, M.J. Holtz Bacha, Ch. (2011). Communicating Governments: a Three-Country Comparison of how Governments Commmunicate with Citizens. The Intenrantional Journal of Press/Politics, 16(4), 523-547. DOI: $10.1177 / 1940161211418225$.

Sanders, K., Canel, M.J. (2013). Introduction: mapping the field of government communication. W: K. Sanders, M.J. Canel (red.). Goverment Communication: Cases and Challenges (s. 1-26). New York, Londyn: Bloomsbury Academic.

Stępińska, A. (2004). Marketingowe strategie wyborcze. Wybory prezydenckie w Polsce (1990-2000). Poznań: Wydawnictwo Naukowe INPiD UAM.

Strömbäck, J. (2008). Four Phases of Mediatization: An Analysis of the Mediatization of Politics. The International Journal of Press/Politics, 13(3), 228-246. DOI: $10.1177 / 1940161208319097$.

Strömback, J. (2009). Selective Professionalisation of Political Campaigning: A Test of the Party-Centred Theory of Professionalised Campaigning in the Context of the 2006 Swedish Election. Political Studies, 57(1), 95-116. DOI: 10.1111/j.1467 -9248.2008.00727.x.

Strömback, J. (2011). Mediatization and Perceptions of the Media’s Political Influence. Journalism Studies, 12 (4), 423-439. DOI: 10.1080/1461670X.2010.523583.

Tenscher, J., Mykkänen, J., Moring, T. (2012). Modes of Professional Campaigning: A Four-country Comparison in the European Parliamentary Elections, 2009. The International Journal of Press/Politics, 17(2), 145-168. DOI: 10.1177/1940161211433839.

Wojcik, K. (2015). Public relations. Wiarygodny dialog z otoczeniem. Warszawa: Oficyna Wolters Kluwer Business.

Wincławska, M., Brodzińska-Mirowska, B. (2016). Niewykorzystane szanse? Partie polityczne w działaniu. Toruń: UMK.

Vliegenthart, R., Boomgarden, H.G., Boumans, J.W. (2011). Changes in a Political News Coverage: Personalization, Conflict and Negativity. W: K. Brants, K. Voltmer (red.). Political Communication in Postmodern Democracy. Challenging the Primacy of Politics (s. 92-110). Hampshire, New York: Palgrave Macmillan. 